\title{
Animal production in Tanzania grass swards fertilized with nitrogen
}

\author{
Marcos Weber do Canto ${ }^{1}$, Amadeu Bona Filho², Aníbal de Moraes ${ }^{2}$, André Ricardo Hoeschl2 \\ Eliane Gasparino ${ }^{1}$
}

\footnotetext{
1 Universidade Estadual de Maringá, Departamento de Zootecnia, Avenida Colombo, no 5.790, CEP: 87020-900, Maringá, Paraná, Brasil. 2 Universidade Federal do Paraná, Departamento de Fitotecnia e Fitossanitarismo, CEP: 80035-050, Paraná, Brasil.
}

ABSTRACT - Nitrogen (N) at 100, 200, 300, and $400 \mathrm{~kg} \mathrm{ha}^{-1}$ was applied to Tanzania grass swards to evaluate the animal response and relationships between sward characteristics and the performance of young Nellore bulls (Bos indicus) under continuous stocking. A completely randomized experimental design was used with two replications between 11 November 2001 and 15 April 2002 when the sward heights were maintained at $60 \mathrm{~cm}$ by using different stocking rates. The average daily gain (ADG) $\left(0.73 \mathrm{~kg} \mathrm{~d}^{-1}\right)$ was not affected by $\mathrm{N}$ doses while the number of animal days ha ${ }^{-1}$ increased linearly from 515 to 1267 . On the other hand, the linear increase in the animal yield was 399, 653, 755, and $895 \mathrm{~kg} \mathrm{ha}^{-1}$ for $\mathrm{N}$ at 100, 200, 300, and $400 \mathrm{~kg} \mathrm{ha}^{-1}$, respectively, while the ratio between the liveweight gain (kg) and $\mathrm{N}\left(\mathrm{kg} \mathrm{ha}^{-1}\right)$ decreased. Correlation coefficients between ADG and herbage mass, green leaf mass, green herbage mass, proportion of green leaf and leaf:culm ratio were low and nonsignificant. Under the conditions in Northwestern Paraná, the application of $\mathrm{N}$ to swards of Tanzania grass is a management option for increasing beef cattle production.

Key Words: animal performance, nitrogen fertilization, Panicum maximum, tropical grass

\section{Produção animal em pastos de capim-tanzânia adubadas com nitrogênio}

RESUMO - Doses de nitrogênio (N) de 100, 200, 300 e 400 kg/ha foram aplicadas em pastos de capim-tanzânia, utilizados sob lotação contínua, visando avaliar a resposta animal e as relações entre características do pasto e o desempenho animal. As avaliações foram realizadas no período de 10 de novembro de 2001 a 15 de abril de 2002 utilizando-se tourinhos da raça Nelore (Bos indicus), em delineamento inteiramente ao acaso com duas repetições. A altura do pasto foi mantida em $60 \mathrm{~cm}$ por meio de ajustes da taxa de lotação. O ganho médio diário (GMD) por animal dos tourinhos foi semelhante entre as doses de $\mathrm{N}$, com média de $0,73 \mathrm{~kg} /$ animal.dia. O número de animais.dia/ha aumentou linearmente com as aplicações de $\mathrm{N}$, de 515 a 1.267. A adubação nitrogenada aumentou de modo linear a produtividade (animal/ha). Nas doses de $\mathrm{N}$ de 100, 200, 300 e $400 \mathrm{~kg} / \mathrm{ha}$, a produtividade animal foi, respectivamente, de 399, 653, 755 e $895 \mathrm{~kg}$ de peso vivo/ha. A razão kg de peso vivo/kg de $\mathrm{N}$ aplicado reduziu com o aumento da dose de $\mathrm{N}$. As correlações entre o GMD por animal e a massa de forragem, a massa de folha verde, a massa de forragem verde, a participação de folha verde e a razão folha:colmo foram baixas e nãosignificativas. Nas condições do noroeste do Paraná, aplicações de N em pastagens de capim-tanzânia são alternativas para aumentar a produção de bovinos de corte.

Palavras-chave: adubação nitrogenada, desempenho animal, gramínea tropical, Panicum maximum

\section{Introduction}

Tropical grasses have been the most important herbage plants for beef cattle production in Paraná State, Brazil, where sward fertilization is still rare under most on-farm conditions. Liming and other mineral nutrients, in conjunction with proper management, have induced higher animal responses to N (Vicente-Chandler, 1974) which is the most important nutrient for increasing both the herbage production and the animal yield (Whitehead, 1995).

Tanzania grass was released in 1990 by the Embrapa Gado de Corte in conjunction with various research institutes (Jank et al., 1994) where results from the various beef cattle regions (Lima et al., 1969; Lugão, 2001; Euclides et al., 2007b) showed that fertilizing Panicum maximum cultivars with $\mathrm{N}$ have had significant responses of animal yield, i.e the liveweight gain, milk or wool production per hectare (Mott, 1981).

High $\mathrm{N}$ doses have increased the ADG evaluated in swards of pearl-millet (Pennisetum americanum (L.) Leeke) under continuous stocking (Moojen et al. 1999), the animal yield and stocking rates (Canto, 2003; Euclides et al., 2007b) and have also modified the sward characteristics of Panicum maximum (Sarmento et al., 
2005; Euclides et al., 2007a). The ADG of young Nellore bulls grazing swards of Tanzania grass was $0.91 \mathrm{~kg} \mathrm{~d}^{-1}$ during the growing season (Canto, 2003) and $0.63 \mathrm{~kg} \mathrm{~d}^{-1}$ in the winter (Canto et al., 2002). Furthermore, Boval et al. (2002), who imposed similar herbage allowance, reported that N applied to Dichathium spp. under intermittent stocking affected the sward height, structural composition, leaf lamina mass, and the crude protein concentration, which were also responsible for modifying the ingestive behavior of Creole heifers. In tropical grasses, the herbage mass and sward heights modified the herbage intake and animal performance (Burns \& Sollenberger, 2002). According to Gontijo Neto et al. (2006), the availability of dry matter (DM), leaves, the sward height, and the leaf:culm ratio had high correlation with the herbage intake of Tanzania grass under different leaf lamina allowances under intermittent defoliation. However, in the Brazilian subtropics, reports of the effects of continuous stocking on the performance of young Nellore bulls grazing Tanzania grass swards fertilized with different $\mathrm{N}$ doses are still rare. The objective of this grazing trial was to verify the effects of four $\mathrm{N}$ fertilization rates on the ADG, herbage allowance, animal yield and stocking rate of Tanzania grass under continuous stocking and the influence of sward characteristics on the ADG of young Nellore bulls.

\section{Material and Methods}

The present experiment was conducted on the Nossa Senhora Aparecida Farm (latitude $23^{\circ} 18$ 'S, longitude 51 $51^{\circ} \mathrm{W}$ and altitude $405.7 \mathrm{~m}$ ), Northwestern Paraná, Brazil. The climate is Cfa with rainy summer and dry winter and the total rainfall observed during the experimental period 10 November 2001 and 15 April 2002 was 788 mm. The average rainfalls in the region were 201.5, 196.6, 153.8, 146.7, and 130.2 mm during December, January, February, March, and April (Deffune et al., 1995).

The experiment was established in a dystroferric red latosol (0xisol) (Embrapa, 1999). Previously, in the 1998/ 1999 growing season, $\mathrm{P}_{2} \mathrm{O}_{5}$ at $180 \mathrm{~kg} \mathrm{ha}^{-1}$ as commercial single super-phosphate and $\mathrm{K}_{2} \mathrm{O}$ at $60 \mathrm{~kg} \mathrm{ha}^{-1}$ as potassium chloride (Comissão de Fertilidade do Solo RS/SC, 1995) were applied to the soil and soon after both fertilizers were incorporated using a tandem disk harrow. $\mathrm{N}$ at $250 \mathrm{~kg} \mathrm{ha}^{-1}$ was also applied as urea. Seeds at $10 \mathrm{~kg} \mathrm{ha}^{-1}$ were also spread on the soil surface and then incorporated at a depth of $1.5 \mathrm{~cm}$ into the soil to establish 8.9 ha of Tanzania grass at the end of September 1998. In the present experiment, a mixture of $\mathrm{P}_{2} \mathrm{O}_{5}$ at $120 \mathrm{~kg} \mathrm{ha}^{-1}$, boron and zinc at $3 \mathrm{~kg} \mathrm{ha}^{-1}$ was applied in September 2001. The chemical analysis indicated a soil with $\mathrm{pH} \mathrm{CaCl}{ }_{2}=5.4, \mathrm{Al}^{+3}=0.0 \mathrm{cmol}_{\mathrm{c}} \mathrm{dm}^{-3}$, $\mathrm{H}^{++} \mathrm{Al}^{+3}=3.66 \mathrm{cmol}_{\mathrm{C}} \mathrm{dm}^{-3}, \mathrm{Ca}^{++}=7.7 \mathrm{cmol}_{\mathrm{C}} \mathrm{dm}^{-3}, \mathrm{~K}^{+}=$ $0.63 \mathrm{cmol}_{C} \mathrm{dm}^{-3}, \mathrm{P}=8.4 \mathrm{mg} \mathrm{dm}^{-3}$, and $\mathrm{C}=14.5 \mathrm{~g} \mathrm{dm}^{-3}$. No liming or potassium fertilization was necessary. A randomized complete design was used with four treatments and two replicates in which $\mathrm{N}$ at $100,200,300$, and $400 \mathrm{~kg} \mathrm{ha}^{-1}$ as ammonium nitrate were divided and one-third was applied in 21 November 2001 and two-thirds in 15 January 2002 at $100 \mathrm{~kg} \mathrm{ha}^{-1}$. Furthermore, three one-third levels were applied in 21 November 2001, 15 January 2002 and 05 February 2002 at 200, 300, and $400 \mathrm{~kg} \mathrm{ha}^{-1}$.

The experimental paddock consisted of an area of approximately 0.9 and 1.1 ha. Every paddock had a trough with mineral salts and a $1000 \mathrm{~L}$ water reservoir which was properly set up on the opposite side. The young Nellore bulls, which were the animals evaluated in the present experiment, had an average liveweight of $300 \mathrm{~kg}$ and were properly wormed one-month before the beginning of the experiment. The grazing method was continuous stocking with variable stocking rate (Mott \& Lucas, 1952). The put-and-take animals were temporarily moved to an adjacent Tanzania grass pasture which was maintained at $60 \mathrm{~cm}$ height.

The sward heights were maintained at $55 \mathrm{~cm}$ in the paddocks fertilized with $\mathrm{N}$ at $100 \mathrm{~kg} \mathrm{ha}^{-1}, 61 \mathrm{~cm}$ for $\mathrm{N}$ at $200 \mathrm{~kg} \mathrm{ha}^{-1}, 62 \mathrm{~cm}$ for $\mathrm{N}$ at 300 and $400 \mathrm{~kg} \mathrm{ha}^{-1}$ by using a ruler for monitoring through 50 measurements which were collected every week at random from ground level up to the arc of the leaf lamina or the extreme of the uppermost leaf. Every month, the herbage mass was evaluated by the double sampling method (Wilm et al. 1944) and the morphological components were harvested within quadrats of $1.00 \mathrm{~m}^{2}$ where the plants were clipped close to the ground. Thereafter, the samples were packed in paper bags and frozen. The herbage mass was calculated by the equation by Gardner (1986). The morphological components, which were previously partitioned into leaf lamina, leaf sheath and culm, and dead material, were oven-dried at $60^{\circ} \mathrm{C}$ for 48 hours.

Three young Nellore bulls were used to evaluate the ADG from every experimental unit under $\mathrm{N}$ at $100 \mathrm{~kg} \mathrm{ha}^{-1}$ and four animal testers were used to evaluate the ADG from every experimental unit which was fertilized with the three other doses. They were weighed after fasting for 14 hours at the beginning and end of the experimental period. The animal yield was calculated by multiplying the ADG versus the number of animal days ha-1 (Mott, 1960). The number of animal days was calculated by using the average number 
of animals per hectare versus the number of grazing days (Mott and Lucas, 1952); the number of animal days or stocking rate was also expressed by the liveweight carried per hectare. The herbage allowance was calculated from the average of the herbage mass, herbage accumulation and the liveweight carried per hectare (Sollenberger et al. 2005).

Analyses of variance and regression (SAS Institute, 2002) were used to investigate the sward characteristics and the animal responses to $\mathrm{N}$ levels. Correlation coefficients between the morphological composition, green leaf lamina, and green herbage mass and the ADG were tested at 5\% probability.

\section{Results and Discussion}

The sward heights which were imposed by the grazing management significantly affected the sward characteristics where the herbage mass, green leaf mass and green herbage mass were linearly increased $(\mathrm{P}<0.05$ ) by $\mathrm{N}$ levels (Table 1 ).

According to Canto et al. (2008), the sward heights of Tanzania grass, under continuous stocking, must be maintained between 40 and $60 \mathrm{~cm}$ at the end of the spring and during the summer. Canto (2003) and Euclides et al. (2007a) who investigated Tanzania grass and Carassai et al. (2008) who investigated natural grasslands, reported that the $\mathrm{N}$ can modify the sward characteristics. In the present case, the herbage mass and green leaf mass were higher than reported by Canto et al. (2008).

The analysis of variance showed nonsignificant differences of $\mathrm{N}$ levels $(\mathrm{P}>0.05$ ) on the ADG (Table 2) which was $0.73 \mathrm{~kg} \mathrm{~d}^{-1}$. This average indicated the cumulative weight gain per animal of $114.6 \mathrm{~kg}$ for 157 days. The leaf:culm ratio was linearly reduced $(\mathrm{P}<0.05)$ from 1.30 to 0.79 (Table 2 ) and no effect of $\mathrm{N}$ levels was detected on the proportion of the green leaf DM which was $335 \mathrm{~g} \mathrm{~kg}^{-1}$ and green herbage DM which was $629 \mathrm{~g} \mathrm{~kg}^{-1}$ ( $\left.\mathrm{P}>0.05\right)$.

Nonsignificant differences in the ADG (Table 2) were caused by the green leaf mass and green herbage mass and the proportion of green leaves on the sward structure (Table 1). ADG of 0.83, 0.73, $0.82 \mathrm{~kg} \mathrm{~d}^{-1}$ (Euclides et al., 1993, Euclides, 1995, Tosi, 1999) were also found in

Table 1 - Herbage mass, green leaf mass, and green herbage mass

\begin{tabular}{lccc}
\hline $\begin{array}{l}\text { N dose } \\
\left(\mathrm{kg} \mathrm{ha}^{-1}\right)\end{array}$ & Herbage mass & $\begin{array}{c}\text { Green leaf mass } \\
(\mathrm{kg} \mathrm{DM} \mathrm{ha})\end{array}$ & Green herbage mass \\
\hline 100 & 6600 & 2335 & 3967 \\
200 & 8100 & 2661 & 4673 \\
300 & 8237 & 3035 & 5444 \\
400 & 9670 & 3204 & 6488 \\
Mean & 8152 & 2809 & 5143 \\
\hline
\end{tabular}

Tanzania grass swards during the growing season. The explanation for similar ADG is that $\mathrm{N}$ improves the crude protein in the leaves of tropical grasses (Lupatini, 1996; Canto, 2003). In addition, high quantities of available herbage induce to bite choices from which the animals select the more palatable parts of the plants (Maraschin, 1997).

Green leaf mass of about $1000 \mathrm{~kg} \mathrm{ha}^{-1}$ (Chacon et al., 1978) maximized the milk yield of grazing cows. The herbage intake and the intake of digestible organic matter of Bothriocloa spp. (Forbes \& Coleman 1993) were improved under green leaf mass of $1000 \mathrm{~kg} \mathrm{ha}^{-1}$. In Brazil, tropical bunch grass swards with leaf lamina mass greater than $1000 \mathrm{~kg} \mathrm{ha}^{-1}$ promoted ADG about $1.0 \mathrm{~kg} \mathrm{~d}^{-1}$ (Setelich, 1999; Almeida et al., 2000; Canto, 2003).

According to Canto (2003), Tanzania grass fertilized with $\mathrm{N}$ at $0,200,400$, and $600 \mathrm{~kg} \mathrm{ha}^{-1}$ under continuous stocking had no influence on the ADG. Furthermore, the ADG of animals in swards of dwarf elephant grass (Pennisetum purpureum Schumach.) cultivar Mott (Setelich 1999) were not significant for $\mathrm{N}$ at $0,250,500$, and $750 \mathrm{~kg} \mathrm{ha}^{-1}$ similarly to that observed in Panicum maximum paddocks by Lugão (2001), who evaluated the effects of $\mathrm{N}$ doses on young bulls raised over spring and summer. Similar responses of ADG to the N level at $250 \mathrm{~kg} \mathrm{ha}^{-1}$ were found in Paraná State where Tanzania grass was grazed by Nellore steers (Watfe, 1999).

The ADG in the present experiment was lower than $1.0 \mathrm{~kg} \mathrm{~d}^{-1}$ which was an average that was obtained from animals evaluated on pearl-millet swards fertilized with $\mathrm{N}$ at $0,150,300,450$, and $600 \mathrm{~kg} \mathrm{ha}^{-1}$ (Lupatini, 1996) and lower than the reports by Setelich (1999) and Almeida et al. (2000), who investigated animal responses on swards of dwarf elephant grass cultivar Mott. The ADG decreased between March and April in Northwestern Paraná where some experiments were also conducted either under intermittent (Lugão, 2001) or continuous stocking (Watfe, 1999; Canto, 2003). This reduction was caused by the presence of reproductive stages and also by herbage

Table 2 - Average daily gain, leaf:culm ratio, green leaf and green herbage proportion

\begin{tabular}{lcccc}
\hline $\begin{array}{l}\text { Dose } \\
\left(\mathrm{kg} \mathrm{ha}^{-1}\right)\end{array}$ & $\begin{array}{c}\text { Average daily } \\
\text { gain } \\
\left(\mathrm{kg} \mathrm{d}^{-1}\right)\end{array}$ & $\begin{array}{c}\text { Leaf:culm } \\
\text { ratio }\end{array}$ & $\begin{array}{c}\text { Green leaf } \\
\left(\mathrm{g} \mathrm{kg}^{-1} \mathrm{DM}\right)\end{array}$ & $\begin{array}{c}\text { Green } \\
\text { herbage }\end{array}$ \\
\hline 100 & 0.77 & 1.30 & 351 & 600 \\
200 & 0.70 & 1.18 & 322 & 583 \\
300 & 0.73 & 0.90 & 346 & 661 \\
400 & 0.71 & 0.79 & 322 & 671 \\
Mean & 0.73 & 1.04 & 335 & 629 \\
\hline
\end{tabular}


aging. Structural modifications in Tanzania grass are caused by the inter-node elongation which occurs before the reproductive stages. Sward height maintained at $60 \mathrm{~cm}$ in Tanzania grass had high crude protein, digestible herbage in the upper strata and leaf lamina mass in March and April; however, the ADG decreased in the autumn when part of the tillers had inter-nodes elongated by the inflorescence development as reported by Canto (2003). Brâncio et al. (2003) also reported reduction in the rate of herbage intake and ADG by steers grazing Tanzania grass in the autumn because of the same structural modifications.

Not significant correlations ( $\mathrm{P}>0.05$ ) were detected between the ADG and the herbage mass ( -0.21$)$, green leaf mass (-0.38), green herbage mass $(-0.29)$, leaf:culm ratio (0.02), proportion of green leaf (0.43) and green herbage $(-0.41)$. These coefficients were affected by the sward height, green leaf mass (Table 1), and the sward structure (Table 2). The upper stratum was also leafy and had high nutritive value because the diet quality is always determined by the sward structure and selective grazing (Boval et al., 2007). On the other hand, Tanzania grass under intermittent stocking and fertilized with $\mathrm{N}$ at 50 or $100 \mathrm{~kg} \mathrm{ha}^{-1}$ at the end of the summer (Euclides et al., 2007b) had significant correlation coefficients between the ADG and leaf lamina mass (0.63) or the leaf:culm ratio (0.90).

There are only a few studies on the mechanisms by which the $\mathrm{N}$ affects the herbage intake rate of tropical grasses (Boval et al., 2002) although it can be affected by the ingestive performance (Burns \& Sollenberger, 2002; Da Silva, 2004). However, the average of sward heights evaluated under different $\mathrm{N}$ levels was very small as well as the modifications in the sward heights. Therefore, these results indicate the need of more studies on $\mathrm{N}$ effects on the relationships between sward measurements, herbage nutritive value and the ADG. Results from Palhano et al. (2006) and Palhano et al. (2007) showed that Mombaça grass grazed at different heights and intermittent defoliation by Holstein heifers modified the animal movement, herbage search and ingestive performance and the animals used compensatory strategy in response to the height and structural composition of the swards. Experiments similar to Palhano et al. (2006) and Palhano et al. (2007) have not yet been conducted on swards of Tanzania grass fertilized with increasing $\mathrm{N}$ levels and continuous stocking.

The relationship between $\mathrm{N}$ levels and the capacity of animal carrying $(C V=10.89)$ (liveweight) which ranged from 1454 to $2195 \mathrm{~kg} \mathrm{ha}^{-1}$ and the number of animal days ha-1 $(\mathrm{CV}=9.39)$ which ranged from 576 to 1288 for $\mathrm{N}$ at 100 and $400 \mathrm{~kg} \mathrm{ha}^{-1}$ were linear (Figure 1).
The highest stocking rate after increasing the $\mathrm{N}$ levels occurred because there were increases in the rate of DM accumulation at higher doses. The DM accumulation rates were $150 \mathrm{~kg} \mathrm{ha}^{-1} \mathrm{~d}^{-1}$ for $\mathrm{N}$ at $100 \mathrm{~kg} \mathrm{ha}^{-1}, 189 \mathrm{~kg} \mathrm{ha}^{-1} \mathrm{~d}^{-1}$ for $\mathrm{N}$ at $200 \mathrm{~kg} \mathrm{ha}^{-1}, 203 \mathrm{~kg} \mathrm{ha}^{-1} \mathrm{~d}^{-1}$ for $\mathrm{N}$ at $300 \mathrm{~kg} \mathrm{ha}^{-1}$, and $259 \mathrm{~kg} \mathrm{ha}^{-1} \mathrm{~d}^{-1}$ for $\mathrm{N}$ at $400 \mathrm{~kg} \mathrm{ha}^{-1}$ (Hoeschl et al., 2007). Previous studies indicated that $\mathrm{N}$ fertilization increased tillering, leaf lifespan, leaf elongation and leaf appearance rates (Setelich, 1999; Canto, 2003). Hernandez Garay et al. (2004) reported that the main effects caused by higher $\mathrm{N}$ levels were the increases in herbage production and stocking rate which must also be increased to achieve an efficient conversion of herbage production into meat. Management is a critical factor for obtaining an efficient use of the high herbage yield of tropical grasses (Fagundes et al. 2005) because the stocking rate in conjunction with $\mathrm{N}$ have significant influence on the animal responses. In the present case, Tanzania grass fertilized with $\mathrm{N}$ at 300 and $400 \mathrm{~kg} \mathrm{ha}^{-1}$ supported stocking rates from 2500 to $3000 \mathrm{~kg} \mathrm{ha}^{-1}$, respectively. Therefore, such results were expected because $\mathrm{N}$ always increases the stocking rate of tropical swards (Moojen et al., 1999; Lugão, 2001; Canto, 2003).
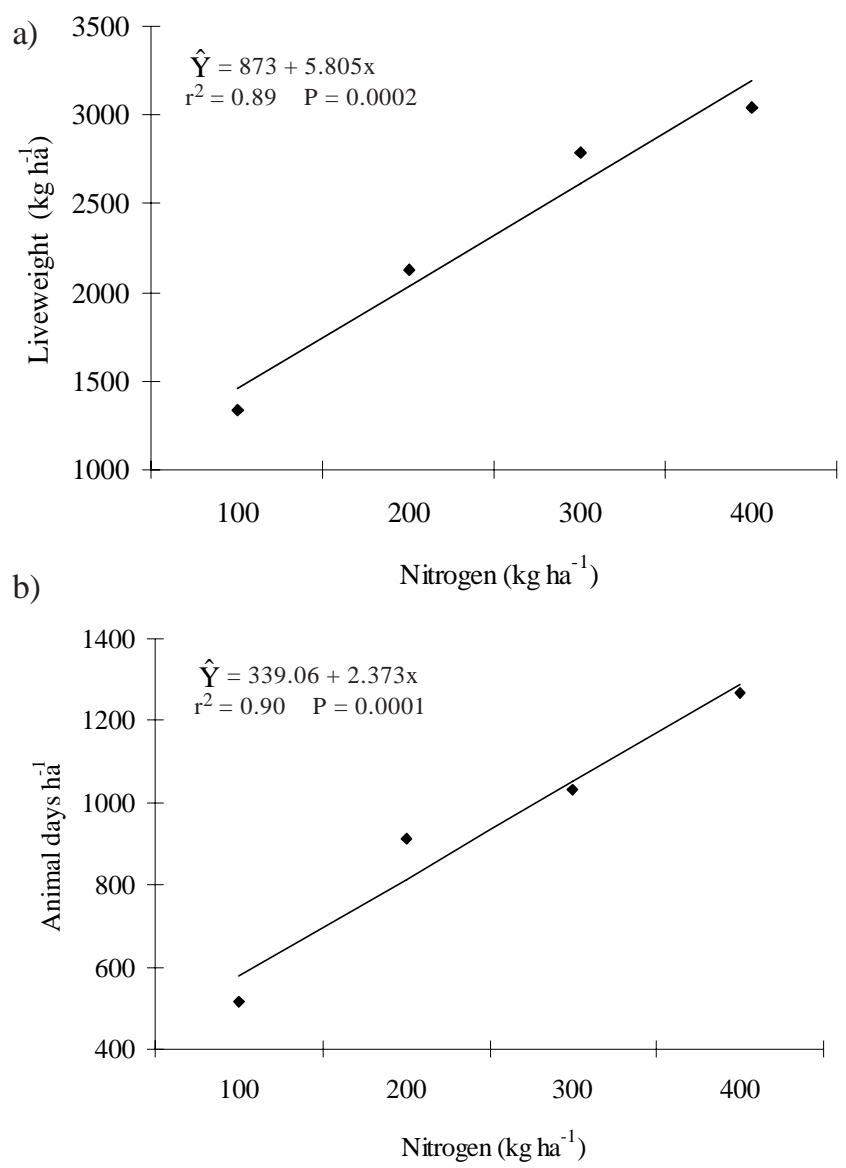

Figure 1 - a) Stocking rate (liveweight, $\mathrm{kg} \mathrm{ha}^{-1}$ ) and b) number of animal days $\mathrm{ha}^{-1}$. 


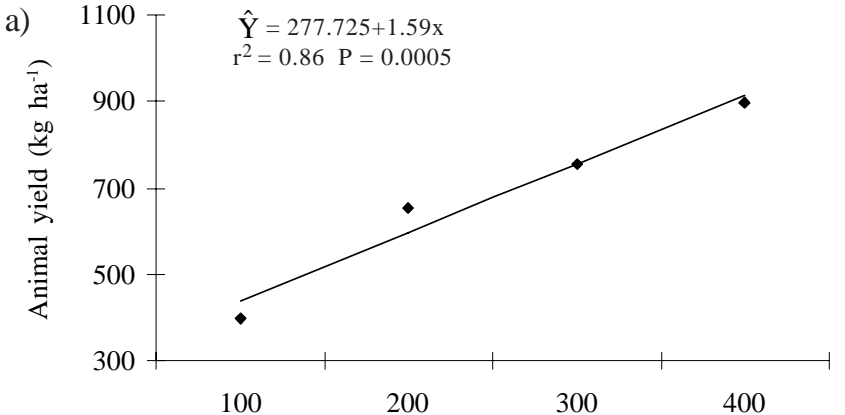

b)

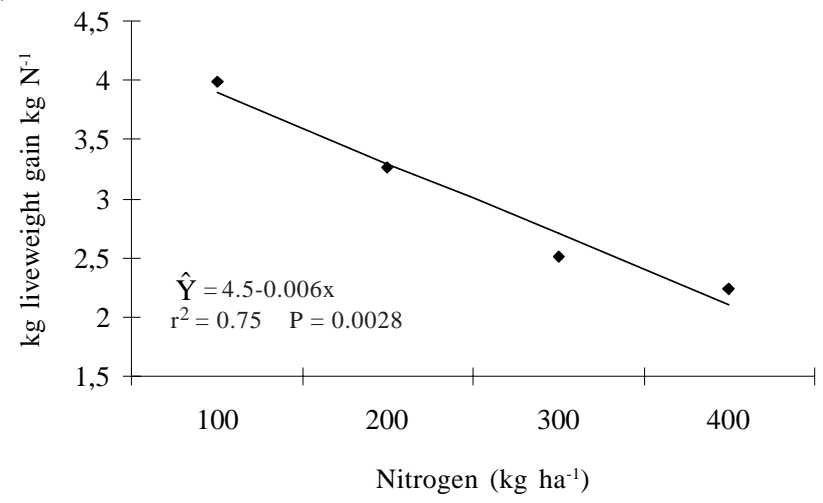

Figure 2 - a) Animal yield (liveweight $\mathrm{ha}^{-1}$ ) and b) the ratio between liveweight and $\mathrm{N}$.

The animal yield was linearly increased (CV=13.11) by $\mathrm{N}$ levels and the ratio between liveweight gain and $\mathrm{N}$ levels decreased linearly ( $\mathrm{CV}=17.47$ ) (Figure 2). Animal yield from swards fertilized with $\mathrm{N}$ at 100, 200, 300, and $400 \mathrm{~kg} \mathrm{ha}^{-1}$ were $399,653,755$, and $895 \mathrm{~kg} \mathrm{ha}^{-1}$ and the ratio between the gain of liveweight and $\mathrm{N}$ ranged from 3.9 to 2.1 .

The animal yield was also affected by the higher stocking rate on those swards fertilized with greater $\mathrm{N}$ levels. The swards fertilized with $\mathrm{N}$ at 100, 200, and $300 \mathrm{~kg} \mathrm{ha}^{-1}$ had 44.6, 72.9 and $84.3 \%$ of animal yield compared to the swards fertilized with $\mathrm{N}$ at $400 \mathrm{~kg} \mathrm{ha}^{-1}$. Such responses were consistent with the higher animal yield from tropical grasses fertilized with higher N levels (Vicente-Chandler, 1974; Lugão, 2001).

The animal yield is also modified by environmental conditions such as soil fertility, rainfall, sunlight as well as the genetic potential of the animals. The weather conditions are important factors which can modify the sward responses to $\mathrm{N}$. Because of the high costs of DM production, the application of $\mathrm{N}$ demands intensive sward management to transform the available herbage into meat (Lugão, 2001).

The efficiency of the animal gain which results from the efficiency of the herbage production and intake was estimated between 1.3 and 4.7 (Mears \& Humphreys, 1974; Jones, 1990; Humphreys, 1991) and 1.8 kg liveweight per kg N (Euclides et al., 2007b). Fagundes et al. (2005) similarly reported (Figure 2) that the efficiency of the higher $\mathrm{N}$ levels was reduced in swards of signalgrass (Brachiaria decumbens Stapf.).

Herbage allowance, which is the result of herbage mass, the rate of DM accumulation and stocking rate, had a quadratic response $\left(\hat{\mathrm{Y}}=39.244-0.1337 \mathrm{X}+0.0002 \mathrm{X}^{2}\right.$; $\left.\mathrm{r}^{2}=0.88 ; \mathrm{P}=0.0024\right)$. The highest herbage allowance from the lowest $\mathrm{N}$ level was caused by fewer animal days $\mathrm{ha}^{-1}$. Boval et al. (2000) showed that high levels of intake and digestibility can be obtained in Dichanthium spp. basedswards under different $\mathrm{N}$ levels and herbage allowances, which were imposed at 80, 125 and $155 \mathrm{~g} \mathrm{DM} \mathrm{kg}^{-1}$ liveweight of heifers. In the present experiment, the herbage allowance from $\mathrm{N}$ at 100, 200,300, and $400 \mathrm{~kg} \mathrm{ha}^{-1}$ was lower than the mean reported by Stobbs (1978) who found $39.8 \mathrm{~kg} \mathrm{DM} \mathrm{cow}^{-1} \mathrm{~d}^{-1}$ from Jersey dairy cows which grazed Panicum maximum cultivar Gatton panic fertilized with $\mathrm{N}$ at $250 \mathrm{~kg} \mathrm{ha}^{-1}$. According to Adjei et al. (1980), who evaluated steers on Cynodon swards, the increase in DM herbage allowance to $63 \mathrm{~g} \mathrm{~kg}^{-1}$ liveweight produced $0.6 \mathrm{~kg} \mathrm{~d}^{-1}$. In the present experiment, the herbage allowance may have induced the animals to a similar herbage intake and such a fact is likely to have induced to similar ADG.

\section{Conclusions}

The higher animal yield and the sward carrying capacity indicated significant animal responses to Tanzania grass fertilized with $\mathrm{N}$ during the spring and summer, in Northwestern Paraná, Brazil. Sward height of Tanzania grass at $60 \mathrm{~cm}$ and fertilized with $\mathrm{N}$ produced herbage mass, green leaf mass, and leaf:culm ratio that allowed similar average daily gain in young Nellore bulls. There were no correlations between sward characteristics, structural composition and animal performance.

\section{Literature Cited}

ADJEI, M.B.; MISLEVY, P.; WARD, C.Y. Response of tropical grasses to stocking rate. Agronomy Journal, v.72, n.5, p.863868, 1980.

ALMEIDA, E.X.; MARASCHIN, G.E.; HARTMANN, O.E.L. et al. Oferta de forragem de capim-elefante anão Mott e o rendimento animal. Revista Brasileira de Zootecnia, v.29, n.5, p.1288-1295, 2000.

BOVAL, M.; CRUZ, P.; LEDET, J.E. et al. Effect of nitrogen on intake and digestibility of a tropical grass grazed by Creole heifers. Journal of Agricultural Science, v.138, n.1, p.73-84, 2002.

BOVAL, M.; CRUZ, P.; PEYRAUD, J.L. et al. The effect of herbage allowance on daily intake by Creole heifers tethered on natural Dichantium spp. pasture. Grass and Forage Science, v.55, n.3, p.201-208, 2000. 
BOVAL, M.; FANCHONE, A.; ARCHIMEDE, H.A. et al. Effect of structure of a tropical pasture on ingestive behaviour, digestibility of diet and daily intake by grazing cattle. Grass and Forage Science, v.62, n.1, p.44-64, 2007.

BRÂNCIO, P.A.; NASCIMENTO JR., D.; EUCLIDES, V.B. et al. Avaliação de três cultivares de Panicum maximum Jacq. sob pastejo: composição da dieta, consumo de matéria seca e ganho de peso animal. Revista Brasileira de Zootecnia, v.32, n.5, p.1037-1044, 2003.

BURNS, J.C.; SOLLENBERGER, L.E. Grazing behavior of ruminants and daily performance from warm season grasses. Crop Science, v.42, n.3, p.873-881, 2002.

CANTO, M.W. Dinâmica de crescimento e produção animal em capim Tanzânia adubado com doses de nitrogênio. 2003. 194f. Tese (Doutorado em Agronomia) - Universidade Federal do Paraná, Curitiba, 2003.

CANTO, M.W.; CECATO, U.; ALMEIDA JR., J. et al. Produção animal no inverno em capim-Tanzânia diferido no outono e manejado em diferentes alturas de pasto. Revista Brasileira de Zootecnia, v.31, n.4, p.1624-1633, 2002.

CANTO, M.W.; JOBIM, C.C.; GASPARINO, E. et al. Características do pasto e acúmulo de forragem em capim-tanzânia submetido a alturas de manejo do pasto. Pesquisa Agropecuária Brasileira, v.43, n.3, p.429-435, 2008.

CARASSAI, I.J.; NABINGER, C.; CARVALHO, P.C.F. et al. Recria de cordeiras em pastagem nativa melhorada submetida à fertilização nitrogenada. 1. Dinâmica da pastagem. Revista Brasileira de Zootecnia, v.37, n.8, p.1338-1346, 2008.

CHACON, E.; STOBBS, T.H.; DALE, M.B. Influence of sward characteristics on grazing behaviour and growth of Hereford steers grazing tropical grass pastures. Australian Journal of Agricultural Research, v.29, n.1, p.89-102, 1978.

COMISSÃO DE FERTILIDADE DO SOLO - RS/SC. Recomendações de adubação e de calagem para os Estados do Rio Grande do sul e Santa Catarina. 2.ed. Passo Fundo: Núcleo Regional Sul-Sociedade Brasileira de Ciência do Solo, 1995. 223p.

DA SILVA, S.C. Fundamentos para o manejo do pastejo de plantas forrageiras dos gêneros Brachiaria e Panicum. In: SIMPÓSIO SOBRE MANEJO ESTRATÉGICO DA PASTAGEM, 2., 2004, Viçosa, MG. Anais... Viçosa, MG: Universidade Federal de Viçosa, 2004. p.347-385.

DEFFUNE, G.; KLOSOWSKI, E.S.; da SILVA, S.M. Concentração e intensidade pluviométrica de Maringá, 1976-1994. Revista Unimar, v.17, n.3, p.489-499, 1995.

EMPRESA BRASILEIRA DE PESQUISA AGROPECUÁRIA EMBRAPA. Sistema brasileiro de classificação de solos. Brasília: 1999. 412p.

EUCLIDES, V.P.B. Valor alimentício de espécies forrageiras do gênero Panicum. In: SIMPÓSIO SOBRE MANEJO DA PAStAGeM, 12., 1995, Piracicaba. Anais... Piracicaba: Fundação de Estudos Agrários Luiz de Queiroz, 1995. p. 245-274.

EUCLIDES, V.B.P., MACEDO, M.C.M., VIEIRA, A. et al. Evaluation of Panicum maximum cultivars under grazing. In: INTERNATIONAL GRASSLANDS CONGRESS, 17., 1993, Palmerston North. Proceedings... Palmerston North: New Zealand Grassland Association, 1993. p.1999-2000.

EUCLIDES, V.P.B.; MACEDO, M.C.M.; ZIMMER, A.H. et al. Características do pasto de capim-tanzânia adubado com nitrogênio no final do verão. Pesquisa Agropecuária Brasileira, v.42, n.8, p.1189-1198, 2007a.

EUCLIDES, V.P.B.; COSTA, F.P.; MACEDO, M.C.M. et al. Eficiência biológica e econômica de pasto de capim-tanzânia adubado com nitrogênio no final do verão. Pesquisa Agropecuária Brasileira, v.42, n.9, p.1345-1355, 2007b.

FAGUNDES, J.L.; FONSECA, D.M.; GOMIDE, J.A. et al. Acúmulo de forragem em pastos de Brachiaria decumbens adubados com nitrogênio. Pesquisa Agropecuária Brasileira, v.40, n.4, p.397-403, 2005.
FORBES, T.D.A.; COLEMAN, S.W. Forage intake and ingestive behavior by cattle grazing Old World Bluestems. Agronomy Journal, v.85, n.4, p.808-816, 1993.

GARDNER, A.L. Técnicas de pesquisa em pastagens e aplicabilidade de resultados em sistemas de produção. Brasília: Embrapa, 1986. 197p.

GONTIJO NETO, M.M.; EUCLIDES, V.P.V.; NASCIMENTO JR., D. et al. Consumo e tempo diário de pastejo por novilhos Nelore em pastagem de capim-tanzânia sob diferentes ofertas de forragem. Revista Brasileira de Zootecnia, v.35, n.1, p.60-66, 2006.

HERNANDEZ GARAY, A.; SOLLENBERGER, L.E.; McDONALD, D.C. et al. Nitrogen fertilization and stocking rate affect Stargrass pasture and cattle performance. Crop Science, v.44, n.3, p.1348-1354, 2004.

HOESCHL, A.R.; CANTO, M.W.; BONA FILHO, A. et al. A produção de forragem e perfilhamento em pastos de capim Tanzânia adubados com doses de nitrogênio. Scientia Agraria, v.8, n.1, p.81-86, 2007.

HUMPHREYS, L.R. Tropical pasture utilization. Cambridge: Cambridge University Press, 1991. 206p.

JANK, L; SAVIDAN, Y.; SOUZA, M.T. et al. Avaliação do germoplasma de Panicum maximum introduzido da África. 1. Produção forrageira. Revista Brasileira de Zootecnia, v.23, n.3, p.433-440, 1994.

JONES, J.R. Nitrogen rate and stocking rate effects on steer gains from grazed irrigated pangola grass in the Ord valley, Western Australia. Australian Journal of Experimental Agriculture, v.30, n.5, p.599-605, 1990.

LIMA, F.P.; SARTINI, H.J.; MARTINELLI, D. et al. Utilização de 4 gramíneas tropicais na produção de carne, em um solo típico Latossolo Roxo. Boletim da Indústria Animal, v.26, p.199-214, 1969.

LUGÃO, S.M.B. Produção de forragem e desempenho animal em pastagens de Panicum maximum Jacq. (acesso BRA006998) adubadas com nitrogênio na Região Noroeste do Paraná. 2001. 151f. Tese (Doutorado em Zootecnia) Universidade Estadual Paulista, Jaboticabal, 2001.

LUPATINI, G.C. Produção animal em milheto (Pennisetum americanum (L.) Leeke) submetido a níveis de adubação nitrogenada. 1996. 129f. Dissertação (Mestrado em Zootecnia) - Universidade Federal de Santa Maria, Santa Maria, 1996.

MARASCHIN, G.E. Produção de carne a pasto. In: SIMPÓSIO SOBRE MANEJO DA PASTAGEM, 13., 1997, Piracicaba. Anais... Piracicaba: Fundação de Estudos Agrários Luiz de Queiroz, 1997. p.243-274.

MEARS, P.T.; HUMPHREYS, L.R. Nitrogen response and stocking rate of Pennisetum clandestinum pastures. 2. Cattle growth. Journal of Agricultural Science, v.83, n.5, p.469-478, 1974.

MOOJEN, E.L.; RESTLE, J.; LUPATINI, G.C. et al. Produção animal em pastagem de Milheto sob diferentes níveis de nitrogênio. Pesquisa Agropecuária Brasileira, v.34, n.11, p.2145-2149, 1999.

MOTT, G.O. Grazing pressure and the measurement of pasture production. In: INTERNATIONAL GRASSLANDS CONGRESS, 8., 1960, Oxford. Proceedings... Oxford: Alden Press, 1960. p.606-611.

MOTT, G.O. Measuring forage quantity and quality in grazing trials. In: SOUTHERN PASTURE AND FORAGE CROP IMPROVEMENT CONFERENCE, 37., 1981, Nashville. Proceedings... Nashville: United States Department of Agriculture, 1981. p.3-9.

MOTT, G.O.; LUCAS, H.L. The design, conduct and interpretation of grazing trials on cultivated and improved pastures. In: INTERNATIONAL GRASSLAND CONGRESS, 6., 1952, Pennsylvania. Proceedings... Pennsylvania: State college Press, 1952. p.1380-1385.

PALHANO, A.L.; CARVALHO, P.C.F.; DITRICH, J.R. et al. Padrões de deslocamento e procura por forragem de novilhas leiteiras 
em pastagem de capim-mombaça. Revista Brasileira de Zootecnia, v.35, n.6, p.2253-2259, 2006.

PALHANO, A.L.; CARVALHO, P.C.F.; DITRICH, J.R. et al. Características do processo de ingestão de forragem por novilhas holandesas em pastagens de capim-mombaça. Revista Brasileira de Zootecnia, v.36, n.4, p.1014-1021, 2007 (supl.).

SARMENTO, P.; RODRIGUES, L.R.A.; LUGÃO, S.M.B. et al. Respostas agronômicas e morfológicas de Panicum maximum Jacq. CV. IPR-86 Milênio, sob pastejo, a adubação nitrogenada. Boletim da Indústria Animal, v.62, p.333-346, 2005.

STATISTICAL ANALYSIS SYSTEM - SAS. SAS user's guide: statistics. Cary: 2002. (CD-ROM).

SETELICH, E.A. Resposta à adubação nitrogenada de capim elefante anão (Pennisetum purpureum Schum. cv. Mott), sob pastejo no Alto Vale do Itajaí, Santa Catarina. 1999. 132f. Tese (Doutorado em Zootecnia) - Universidade Federal do Rio Grande do Sul, Porto Alegre, 1999.

SOLLENBERGER, L.E.; MOORE, J.E.; ALLEN, V.G. et al. Reporting forage allowance in grazing experiments. Crop Science, 2005, v.45, n.3, p.896-900, 2005.

STOBBS, T.H. Milk production, milk composition, rate of milking and grazing behaviour of dairy cows grazing two tropical grass pastures under a leader and follower system. Australian Journal of Experimental Agriculture and Animal Husbandry, v.18, n.1, p.5-11, 1978.

TOSI, P. Estabelecimento de parâmetros agronômicos para o manejo e eficiência de utilização de Panicum maximum Jacq. Tanzânia-1 sob pastejo rotacionado. 1999. 103f. Dissertação (Mestrado em Zootecnia) - Escola Superior de Agricultura Luiz de Queiroz, Piracicaba, 1999.

VICENTE-CHANDLER, J. Fertilization of humid tropical grasslands. In: MAYS, D.A. (Ed.) Forage fertilization. Madison: American Society of Agronomy, Crop Science Society of America, Soil Science Society of America, 1974. p.277-300.

WATFE, E. Relação entre o desempenho por animal e características de uma pastagem de capim Tanzânia-1 manejada em diferentes alturas de pastagens. 2001. 23f. Trabalho (Graduação em Zootecnia) - Universidade Estadual de Maringá, 2001, Maringá.

WHITEHEAD, D.C. Grassland Nitrogen. Wallingford: CAB International, 1995. 397p.

WILM, H.G.; COSTELLO, O.F.; KLIPPLE, G.E. Estimating forage yield by the double sampling method. Journal American Society of Agronomy, v.36, n.3, p.194-203, 1944. 